\title{
LDL 抗酸化能に及ぼす加齢の影響
}

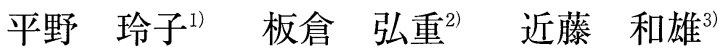

\begin{abstract}
〈要 約〉 酸化した低比重りポ蛋白（LDL）はマクロファージや平滑筋細胞に取り込まれ，動脈硬化病変 部に数多く認められる泡沫細胞を形成させることから, 動脈硬化の発症, 進展に深く関与する重要な因子と 考えられている。一方，加齢に伴い，血清脂質が増加することや生体内抗酸化酵素の活性が低下することが 知られており，これは LDL の酸化を介して動脈硬化発症の機会を増すことが推察される．本研究では LDL 抗酸化能に及ぼす加齢の影響に焦点をおき，その関連性を検討した。健常成人306名（男性169名，女性137 名）を対象に LDL 抗酸化能を測定した結果，LDL の酸化平均 lag time は58.9 $1.0 \mathrm{~min}$ であり，20代で80.3 $\pm 4.8 \mathrm{~min}$ と最も長く，40代で $54.1 \pm 1.6 \mathrm{~min}$ と最も短かった．性差年齢階層別に比較すると，20代男性が最も 長く $(88.9 \pm 6.2 \mathrm{~min}), 40$ 代女性は最も短い $(50.7 \pm 2.2 \mathrm{~min})$ ことが認められ, 生化学検查で異常を認めた対 象者を除外しても同様の結果が示された，次に lag timeに影響を与える因子に関して，全例を対象に重回 帰分析にて検討した結果，年噛階層および尿酸（UA），LDL-コレステロール（LDL-C）の各変数が有意と なり, LDL 抗酸化能は加齢および加龃に伴う LDL-C の変動，さらには生体内抗酸化機能の増減に影響を受 けていることが示唆された。
\end{abstract}

Key words : 加齢，動脈硬化，LDL 抗酸化能，抗酸化物質，LDL-コレステロール

（日老医誌 $2001 ； 38 ： 372-376$ )

\section{緒言}

老齢者において脳血管障害や冠動脈疾患などの動脈硬 化性疾患は, 死因の大半を占めている. 加齢により総コ レステロール（TC）值の増加が報告されており，なか でも LDL-コレステロール (LDL-C) がその変動に強く 影響している ${ }^{1)}$.こうした低比重リポ蛋白 (LDL) の量 の重要性に加えて, LDL の酸化変性が動脈硬化症の発 症，進展に打けるリスクファクターとして注目を集めて いる ${ }^{2)}$. 生体内には LDL の酸化を抑制する抗酸化システ ムが存在するが，加齢に伴い，生体内抗酸化酵素である スーパーオキシドジムスターゼやカタラーゼ，グルタチ オンペルオキシダーゼの低下が報告されている3.

このように，加齢による抗酸化システムの機能低下お よび血清脂質の増加，さらには LDL の易酸化的環境へ の曝露など, LDL の酸化変性は動脈硬化性疾患を介し て老化と結びついている. 本研究では LDL 抗酸化能に 及ぼす加齢の影響に焦点をおき,その関連性を検討した。

\section{方法}

対象は，人間ドック受診者を中心とした健常成人306 名で, 男性169名, 女性137名で, 年齢階層分布は20歳か

1）R. Hirano：防衛医科大学校内科学第一講座

2) H. Itakura：茨城キリスト教大学生活科学部

3）K. Kondo：抢茶の水女子大学生活環境研究センター

受付日：1999.2.24，採用日：2000.10.24
ら81歳，平均 $48.5 \pm 0.7$ (標準誤差) 歳である.

12 時間絶食後の早朝空腹時に採血を行い，血漿を分離 後, TC, 遊離コレステロール $(\mathrm{FC})$, トリグリセリド (TG), リン脂質 $(\mathrm{PL})$, 遊離脂肪酸 $(\mathrm{NEFA})$, 尿酸 $(\mathrm{UA})$ は酵素法, HDL コレステロール（HDL-C）はマグネシ ウム沈殿法, アルブミン (ALB) は比色法により測定

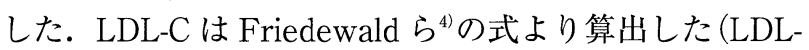
$\mathrm{C}=\mathrm{TC}-\mathrm{HDL}-\mathrm{C}-0.2 \times \mathrm{TG})$. LDL 抗酸化能の測定のた

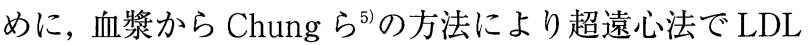
$(1.019<\mathrm{d}<1.063)$ を分取し, LDL の蛋白量を BCA protein assay kit (Pierce Laboratories Inc., IL) で測定し た. Esterbauer $\mathrm{H}^{\left.{ }^{6}\right)}$ の変法に従い, LDL の蛋白濃度 を $70 \mu \mathrm{g} / \mathrm{ml}$ に調製後, $200 \mu \mathrm{M}$ のアゾ化合物 ; 2-2' -azobis (4-methoxy-2, 4-dimethylvaleronitrile) により LDL を 強制的に酸化させ，共役ジエンが生成するまでの時間 (lag time）を指標として測定した7).

数値は mean \pm standard error（SE）で示した. 統計 的有意差検定は分散分析を用いて行い, 年齢階層間の比 較は Fisher's protected least significant difference 検定 により，性別 2 群間の比較は Student's t-testにより5\% 水準以上で有意とした．各項目の相関は単回帰分析によ り検定し, 重回帰分析は lag time を被説明変数, 年齢 階層および単回帰分析にて相関性を呈した項目を説明変 数として検討した. なお，年齢階層は 20 代を基準として 各年齢階層別にダミー変数を割り当てた.すべての統計 処理は StatView J 4.5により行った. 
Table 1 Characteristics of subjects*

\begin{tabular}{l|r}
\hline Parameter $(\mathrm{mg} / \mathrm{d} l)$ & Mean $\pm \mathrm{SE}$ \\
\hline TC & $202.9 \pm 2.1$ \\
FC & $51.3 \pm 0.5$ \\
TG & $107.7 \pm 3.8$ \\
PL & $209.5 \pm 1.7$ \\
NEFA & $0.5 \pm 0.0$ \\
LDL-C & $127.3 \pm 1.9$ \\
HDL-C & $54.1 \pm 0.9$ \\
UA & $4.9 \pm 0.1$ \\
ALB & $4.6 \pm 0.0$ \\
\hline
\end{tabular}

$*_{n}=306(169$ male, 137 female $)$

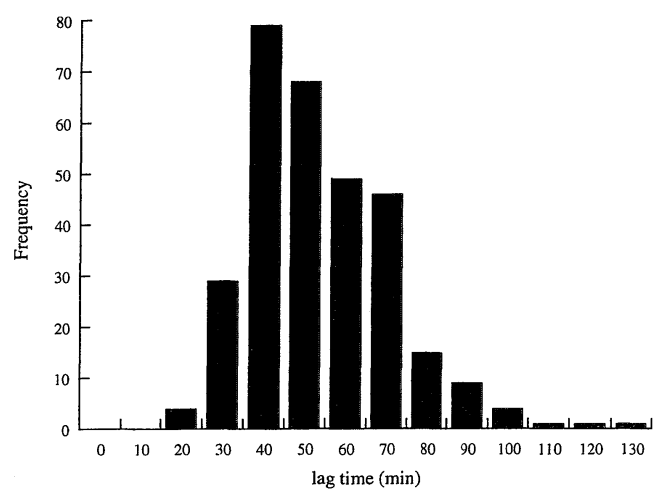

Fig. 1 Frequency distribution curve of LDL oxidisability in subjects. The oxidation of LDL $(70 \mu \mathrm{g} / \mathrm{m} l)$ was initiated by $200 \mu \mathrm{M}$ V-70. Data was obtained from $\mathrm{n}=$ 306 of subjects. The mean $\pm \mathrm{SE}$ of lag time was $58.9 \pm$ $1.0 \mathrm{~min}$

\section{結 果}

対象者の生化学検査の結果を Table 1 に示す. 測定し た TC, FC, TG, PL, NEFA, LDL-C, HDL-C, UA, ALB の各平均值はいずれも正常範囲内にあった.

本対象者における lag time の頻度分布は Fig. 1 に示す ように，27min〜 133minの範囲にあり40min および50 min 台に頻度は集中した。平均 lag time は58.9 $\pm 1.0 \mathrm{~min}$ であった，年齢階層別に lag time を比較した結果，20

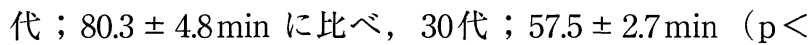
$0.0001) ， 40$ 代 ; 54.1 $\pm 1.6 \min (\mathrm{p}<0.0001) ， 50$ 代 ; 57.6 $\pm 1.5 \min (\mathrm{p}<0.0001) ， 60$ 代 $; 65.8 \pm 2.9 \min (\mathrm{p}<0.005)$ ， 70 代以上； $68.4 \pm 3.7 \mathrm{~min}$ (n.s.) であり，20代で最も長く， また40代において最も短かった（Fig. 2). また全対象者 の性差における有意差は認められなかった（男性60.3土 1.3min，女性57.1 $\pm 1.5 \mathrm{~min} ;$ Fig. 3） が，性差年齢階層別 に比較した結果，20代男性が最も長く $(88.9 \pm 6.2 \mathrm{~min})$, 40 代女性は最も短い $(50.7 \pm 2.2 \mathrm{~min})$ ことが認められた (Fig. 4).

加齢による lag time の変動をさらに言及するために,

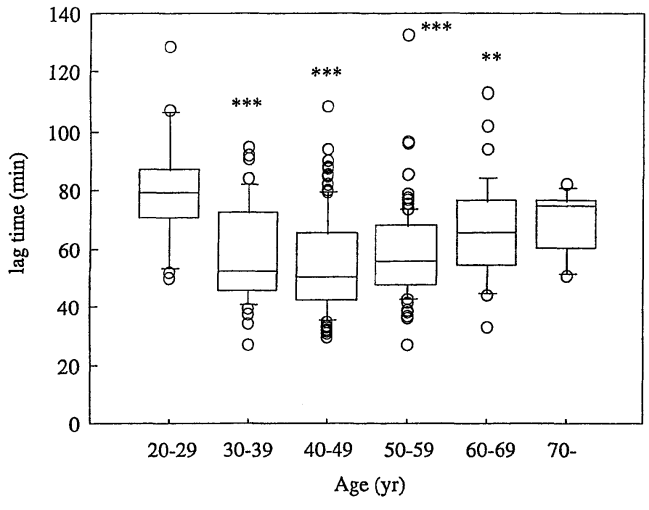

Fig. 2 Effects of aging on LDL oxidisability. The number of each generation was $20 \mathrm{~s}: 17,30 \mathrm{~s}: 41,40 \mathrm{~s}: 108$, $50 \mathrm{~s}: 96,60 \mathrm{~s}: 35$ and over $70: 9$. Statistical comparisons of groups were made using one-way ANOVA and each group was compared with each other by Fisher's PLSD test. Statistical differences are shown as ${ }^{* *} \mathrm{p}<0.005,{ }^{* * *} \mathrm{p}<0.0001$ relative to 20 s.

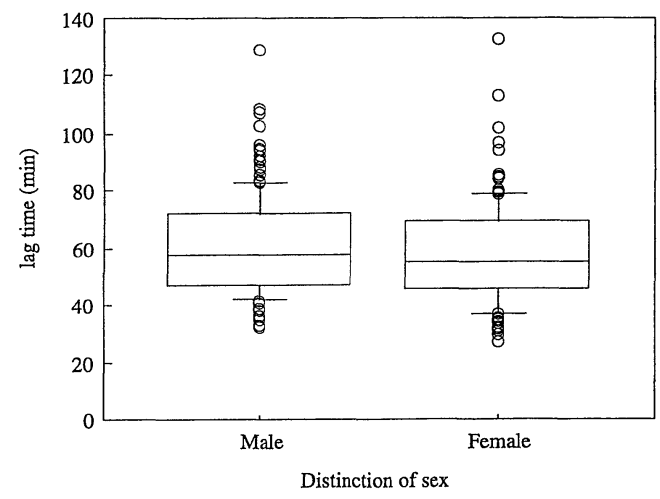

Fig. 3 Effects of sex-distinction on LDL oxidisability. The number of male and female was 169 and 137, respectively. Differences between the groups were examined by two-tailed $t$-tests and comparisons within the groups by paired $t$-tests. The levels of significance were set at $\mathrm{p}<0.05$.

生化学検査で異常を認めた151名 (20代18\%，30代37\%， 40 代 $45 \% ， 50$ 代 $63 \% ， 60$ 代 $54 \% ， 70$ 代 以上 $56 \%$ ）を除 外して lag time を比較した結果, 20 代；79.6 $\pm 5.8 \mathrm{~min}$ に 比 ベ, 30 代 ; $61.6 \pm 3.8 \min (\mathrm{p}<0.005) ， 40$ 代 ; $53.6 \pm 2.1$ $\min (\mathrm{p}<0.0001), 50$ 代 $; 56.7 \pm 3.0 \mathrm{~min}(\mathrm{p}<0.0001), 60$ 代 ; $69.9 \pm 4.5 \mathrm{~min}$ (n.s.)，70代以上；69.2 $\pm 5.5 \mathrm{~min}$ (n.s.) であり，Fig. 2 と同様，20代で最も長く，また 40 代にお いて最も短かった（Fig. 5). また, 性差年齢階層別に比 較した結果，Fig. 4 と同様，20代男性が最も長く（88.7 $\pm 7.0 \mathrm{~min}) ， 40$ 代女性は最も短い $(51.5 \pm 2.8 \mathrm{~min})$ ことが 認められた（Fig. 6).また，全対象者において lag time と各影響因子を単回帰分析にて解析した結果，UA（p 


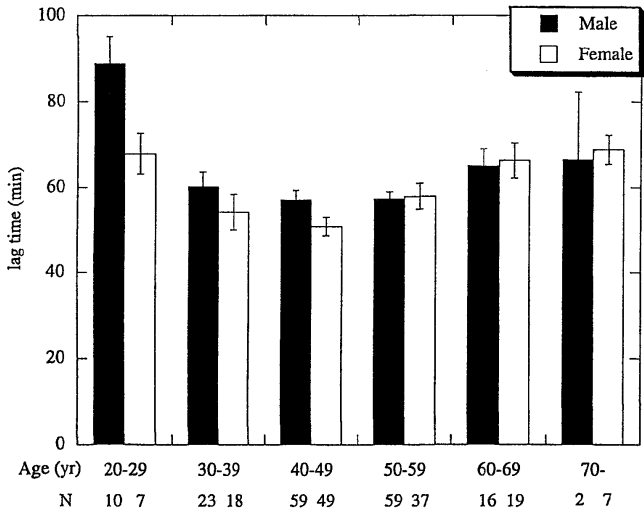

Fig. 4 Effects of aging on LDL oxidisability in the distinction of sex. The number of generation in the distinction of sex was expressed as $\mathrm{N}$ in graph. Data was presented as mean $\pm \mathrm{SE}$.

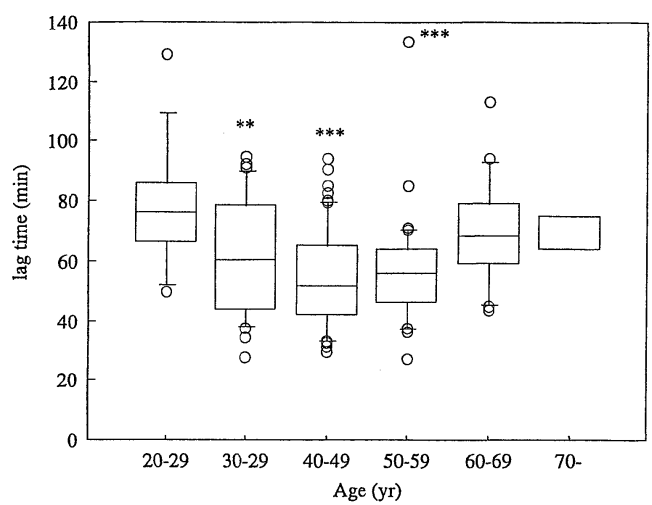

Fig. 5 Effects of aging on LDL oxidisability except subjects who had abnormal biochemical data (total cholesterol, triglyceride, GOT, GPT, $\gamma \mathrm{GTP}$, creatinine and glucose). The number of each generation was $20 \mathrm{~s}: 14$, $30 \mathrm{~s}: 26,40 \mathrm{~s}: 59,50 \mathrm{~s}: 36,60 \mathrm{~s}: 16$ and over $70: 4$. Statistical analysis was performed as fig. 2 . Statistical differences are shown as ${ }^{* *} \mathrm{p}<0.005,{ }^{* * *} \mathrm{p}<0.0001$ relative to 20 s.

$<0.0001)$, TC $(\mathrm{p}<0.05)$, LDL-C $(\mathrm{p}<0.05)$ において 有意な相関を認めた（Table 2$)$.

次に lag time に影響を与える因子を検討するために, lag time を被説明変数, 年齢および性別, 単回帰分析に て相関性を呈したUA，TC，LDL-C を説明変数として， 全対象者において重回帰分析を行った結果，年歯令および UA, LDL-C の各変数が有意となり, lag time に影響を 与えることを認めた (Table 3 ).

\section{考察}

老化の機構には種々の因子が関与しており, 多くの老 化学説が示されているが，なかでもフリーラジカル説8) は各種疾患を惹起することにつながることからも注目さ

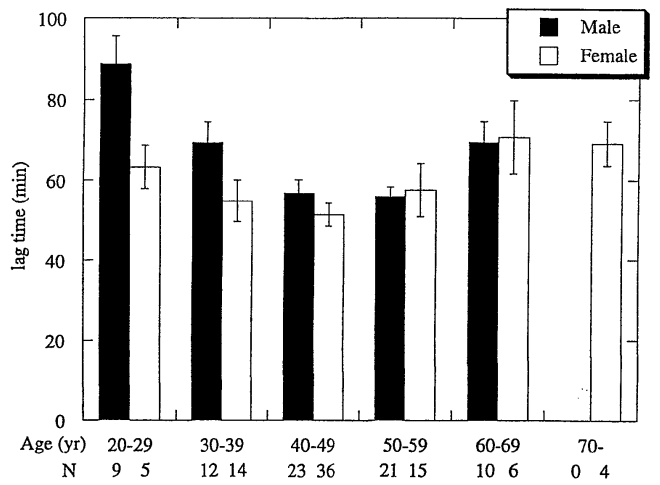

Fig. 6 Effects of aging on LDL oxidisability in the distinction of sex except subjects who had abnormal biochemical data (total cholesterol, triglyceride, GOT, GPT, rGTP, creatinine and glucose). The number of generation in the distinction of sex was expressed as $\mathrm{N}$ in graph. Data was presented as mean $\pm \mathrm{SE}$.

Table 2 Correlation between lag time and other factors except aging. Linear regression analysis was carried out with TC, FC, TG, PL, NEFA, LDL-C, HDL-C, UA or ALB as independent variables and lag time as dependent variables.

\begin{tabular}{lcc}
\hline & \multicolumn{2}{c}{ lag time } \\
\cline { 2 - 3 } & $\mathrm{r}$ & $\mathrm{p}$ value \\
\hline TC & 0.119 & $<0.05$ \\
FC & 0.106 & 0.06 \\
TG & 0.099 & 0.10 \\
PL & 0.061 & 0.29 \\
NEFA & 0.103 & 0.07 \\
LDL-C & 0.143 & $<0.05$ \\
HDL-C & 0.066 & 0.25 \\
UA & 0.341 & $<0.0001$ \\
ALB & 0.010 & 0.86 \\
\hline
\end{tabular}

れている. また, フリーラジカルは動脈硬化の発症, 進 展に深く関与している酸化 LDL を生成し，心疾患や脳 梗塞などを誘発させる危険因子としても知られている. 加齢と心疾患の関係について，1949年にはじまり，現在 も進行中である Framingham Study ${ }^{9}$ では, 非契煙者で 正常血圧の若年者（35歳）と老年者（65歳）男性におけ る向こう 6 年間に心疾患を発症する確率は，35歳に比べ 65歳で 2 倍以上高くなることが報告されている. また加 齢に伴い, 血中の LDL-C は上昇する ${ }^{110)}$. これは老化に より LDLの fractional catabolic rateの低下 ${ }^{11)}$ に加え, production rate の増加 ${ }^{12}$ が生じることに起因するもので あることが報告されている，データは示さなかったが今 回の検討においても加齢とともに LDL-C が上昇する結 果を認めた。 
Table 3 Effects of aging, TC, LDL-C and UA on lag time. Multiple linear regression analysis was carried out with age, TC, LDL-C and UA as independent variables and lag time as dependent variables. Dummy variables which 20 s was a criterion were used in age groups. The correlation coefficient in this analysis was $0.50(\mathrm{p}<0.0001)$.

\begin{tabular}{lcr}
\hline & \multicolumn{2}{c}{ lag time } \\
\cline { 2 - 3 } & $\begin{array}{c}\text { regression } \\
\text { parameters }\end{array}$ & $\mathrm{t}$ value \\
\hline $30 \mathrm{~s}$ & -19.72 & -4.42 \\
$40 \mathrm{~s}$ & -21.72 & -5.29 \\
$50 \mathrm{~s}$ & -18.95 & -4.54 \\
$60 \mathrm{~s}$ & -10.77 & -2.31 \\
$70 \mathrm{~s}$ & -4.911 & -0.76 \\
TC & -0.068 & 1.13 \\
LDL-C & -0.131 & -1.97 \\
UA & 3.823 & 6.11 \\
\hline
\end{tabular}

LDL 抗酸化能の測定については TBARS 法や共役ジ エン法などが利用されているが，今回，我々は酸化誘導 に伴い増加する共役ジエンを測定し, 共役ジエンが生成 するまでの時間 lag time を記録した7).この方法により LDL の抗酸化能と心疾患との関連性が明らかにされて 以来 ${ }^{13}$, 動脈硬化との関連で LDL の抗酸化能を示す指 標の一つとして重要視されており, 現時点では最適な測 定法と考えられる.

本研究において, 動脈硬化危険因子である LDL 抗酸 化能が加齢による影響を受けるか否か検討したところ, 全対象者における検討および生化学検查で異常を認めた 対象者を除外した検討のいずれにおいても, lag time は 20代から40代にかけて短縮し，40代から70代にかけて再 び延長する 2 次曲線を描いた (Fig. 2,5). Stulnig TM $ら^{14)}$ は LDL の抗酸化能に関し, 老齢者（65～80歳）お よび若齢者（18～30歳）で検討した結果，老齢者よりも むしろ若龄者で LDL の酸化が充進していることを報告 している。また Schmuck A ら ${ }^{15)}$ は健常な老齢者 $(59 \sim 80$ 歳) および若齢者 (22〜29歳) を対象に検討しているが, LDLの抗酸化能に求いても血中抗酸化物量に扔いても 有意差を認めず, 健常な老齢者では LDL の酸化は動脈 硬化発症・進展に重要な意味をなさないであろうとの見 解を示している.

今回, 我々は年齢階層別に LDL 抗酸化能の検討を行っ たが，20代と70代以上の比較では有意な差が認められな かった.この結果は Schmuck A ら ${ }^{15)}$ の報告と一致して いる．また，有意差は認めなかったが，中高年者 $(40,50$ 代）に比し，60,70代以上で LDL 抗酸化能が充進した結 果について, 本試験に参加した 60 代, 70 代の対象者はゲー トボールを愛好するなど健常で日常的に運動量が適切 で，また簡易な食事調查からも味噌，酱油など大豆フラ ボンを中心とする抗酸化物の多い日本食を主体とする食
生活を送っていたことも要因として考えられる．日本の 食生活はお茶や大豆製品など極めて抗酸化物の多いこと が特徵としてあげられるが，近年，Zutphen elderly stu$\mathrm{dy}^{16)}$ において，抗酸化物（フラボノイド）の摂取の違い により虚血性心疾患の発症に差のあることが示された。

これらの報告は, 加齢により生体内の抗酸化機能が低下 した場合には，低下した生体内抗酸化機能を補うために 抗酸化物を積極的に食事などから取り入れることが，生 体過酸化を防ぐ上で重要であることを示唆している．ま た今回，簡便な食事調查（抗酸化サプリメント摂取の有 無・前日の食事記録）に留まったが，今後，抗酸化物摂 取状況を基本とした詳細な食事調査の検討が重要である と思われた.

LDL 抗酸化能に及ぼす性差の影響に関して, 男女間 においては有意な差は認められなかったが (Fig. 3)，性 差年齢別で検討した結果，20～40代では男性に比し女性 において LDL 抗酸化能は低下することを認めた. 閉経 前女性ではエストロゲンの作用により LDLの抗酸化能 を充進させるとの報告が多く行われている ${ }^{\mathrm{ex} .17)}$. 今後, 例数を増やし, 更なる検討が必要である.

加齢を除外した LDL 抗酸化能に影響を与える因子の 検討から, 生体内抗酸化物質のUA が有意な正の相関 を,また TC, LDL-C が有意な負の相関を認めた(Table 2).このため重回帰分析にて lag time に影響を与える 因子を解析したところ, LDL 抗酸化能は加齢および加 齢に伴う LDL-C の変動, さらには生体内抗酸化機能の 増減に影響を受けている可能性が示唆された (Table 3). LDL の代謝は加齢と共に, LDL 受容体機能の低下をは じめとした fractional catabolic rate の低下 ${ }^{11} や$ production rate の増加 ${ }^{12}$ が生じ遅延するが，このことにより LDL 内の抗酸化物質の消耗を招き, LDL の抗酸化能を変化 させる可能性も考えられる.また，LDL受容体を欠損 する家族性高コレステロール血症患者を対象に, LDL apheresis 前後の LDL 抗酸化能を検討した結果, LDL-C の $62.6 \%$ 低下に伴い, apheresis 後で前よりも $9.8 \%$ lag time 増加が認められた ${ }^{18)}$.このことは LDL-C の低下が LDL 抗酸化能の亢進に結びつく可能性を示唆している. UA に関しては，これまで痛風発作との関連で悪玉視さ れることも多かったが, UAのもつ抗酸化性を考えると 生体内での抗酸化物としての役割を無視することができ ない. 今回の結果でも UA 值と LDL 抗酸化能との強い 正の相関がみられ, 痛風発作をおこさない濃度範囲での, UA の生体内における抗酸化物としての役割をあらため て見直す必要のある結果となった．また今回は, ビ夕ミ ン $\mathrm{E}$ や C どの食事由来抗酸化物の血中濃度および抗 酸化酵素の検討は行っていないが，これらの抗酸化成分 とUA の相互作用に関する報告(6) なされているため, 今後, この点も踏まえて検討を行う必要がある.

加齢は, 脂質の代謝回転が低下寸るだけでなく, 生体 内抗酸化酵素の低下をも招く現象である. LDL 抗酸化 能は加齢, 脂質変動, 生体内抗酸化物質に影響を受ける という本結果を踏まえ, 動脈硬化関連疾患を予防するた 
めに血中コレステロール濃度の改善，抗酸化物質の摂取 を見直すことが重要であろう。

\section{文献}

1) Rifkind BM, Tamir I, Heiss G, Wallace RB, Tyroler HA : Distribution of high density and other lipoproteins in selected LRC prevalence study populations: a brief survey. Lipids $1979 ; 14: 105-12$.

2) Steinberg D, Parthasarathy S, Carew TE, Khoo JC, Witztum JL: Beyond cholesterol. Modifications of low-density lipoprotein that increase its atherogenicity. $\mathrm{N}$ Engl J Med 1989;320:915一24.

3）平井俊策：老化と活性酸素. 抗酸化物質（二木鋭雄，島 崎弘幸, 美濃 真編), 学会出版センター, 東京, 1994, p317-327.

4) Friedewald WT, Levy RI, Fredrickson DS : Estimation of the concentration of low-density lipoprotein cholesterol in plasma, without use of the preparative ultracentrifuge. Clin Chem 1972; 18:499-502.

5) Chung BH, Segrest JP, Ray MJ, Brunzell JD, Hokanson JE, Krauss RM, Beaudrie K, Cone JT: Single vertical spin density gradient ultracentrifugation. Methods Enzymol $1986 ; 128$ : 181-209.

6) Esterbauer H, Striegl G, Puhl H, Rotheneder M : Continuous monitoring of in vitro oxidation of human low density lipoprotein. Free Rad Res Comms 1989; 6: 67-75.

7) Hirano R, Kondo K, Iwamoto T, Igarashi O, Itakura H : Effects of antioxidants on the oxidative susceptibility of low-density lipoprotein. J Nutr Sci Vitaminol 1997;43: 435-444.

8) Harman D : Aging: a theory based on free radical and radiation chemistry. J Gerontol $1956 ; 11$ : 293-300.

9) AMERICAN HEART ASSOCIATION:Coronary Risk Handbook. Estimating risk of coronary heart disease in daily practice. American Heart Association. 1973; 1-50.

10) The Lipid Research Clinics Program Epidemioligy Committee: Plasma lipid distributions in selected North American populations: The Lipid Research Clinics Program Prevalence Study. Circulation 1979;60:427.

11) Miller NE: Why does plasma low density lipoprotein concentration in adults increase with age? Lancet 1984; $1: 263-267$.

12) Grundy SM, Vega GL, Bilheimer DW : Kinetic mechanisms determining variability in low density lipoprotein levels and rise with age. Arteriosclerosis $1985 ; 5: 623-$ 630.

13) Schumacher M, Eber B, Tatzber F, Kaufmann P, Esterbauer $\mathrm{H}$, Klein $\mathrm{W}$ : LDL oxidation and coronary atherosclerosis. Lancet $1992 ; 340: 123$.

14) Stulnig TM, Jurgens G, Chen $Q$, Moll D, Schonitzer D, Jarosch E, Wick G: Properties of low density lipoprotein relevant to oxidative modifications change paradoxically during aging. Atherosclerosis $1996 ; 126: 85-94$.

15) Schmuck A, Fuller CJ, Devaraj S, Jialal I: Effect of aging on susceptibility of low-density lipoprotein to oxidation. Clin Chem 1995; $41: 1628-1632$.

16) Hertog MG, Feskens EJ, Hollman PC, Katan MB, Kromhout D : Dietary antioxidant flavonoids and risk of coronary heart disease : the Zutphen Elderly Study. Lancet $1993 ; 342: 1007-1011$.

17) Arteaga E, Rojas A, Villaseca $P$, Bianchi $M$ : The effect of 17beta-estradiol and alpha-tocopherol on the oxidation of LDL cholesterol from postmenopausal woman and the minor effect of gamma-tocopherol and malatonin. Menopause $2000 ; 7: 112-116$.

18) Donner MG, Parhofer KG, Richter WO, Schwandt P: Low-density lipoprotein (LDL) oxidizability before and after LDL apheresis. Metabolism 1999; $48: 881-886$.

\title{
Abstract
}

\section{Effects of Aging on Oxidisability of Low Density Lipoprotein}

\author{
Reiko Hirano ${ }^{1)}$, Hiroshige Itakura ${ }^{2)}$ and Kazuo Kondo ${ }^{3)}$
}

Oxidised LDL is taken up by macrophages via scavenger receptors, leading to foam cell formation and is thus considered to contribute to atherogenesis. Aging results in the increase of lipids and the decrease of antioxidant enzyme activity in serum. In this study, we investigated the effects of aging on LDL oxidisability. We measured LDL oxidation lag time, plasma lipids, albumin and uric acid were examined in 306 Japanese (169 men, 137 women). The mean \pm SE of LDL oxidation-lag time in subjects was $58.9 \pm 1.0 \mathrm{~min}$. The lag time $(80.3 \pm 4.8 \mathrm{~min})$ was longest in subjects in their $20 \mathrm{~s}$ and shortest in those in their $40 \mathrm{~s}(58.9 \pm 1.0 \mathrm{~min})$. The longest lag time was in second-decade men $(88.9 \pm 6.2 \mathrm{~min})$ and shortest in fourth-decade women $(50.7 \pm 2.2 \mathrm{~min})$, and these results were similar even excluding subjects with abnormal biochemical data (total cholesterol, triglyceride, GOT, GPT, $\gamma \mathrm{GTP}$, creatinine and glucose). We analyzed the effects of various factors on lag time using multiple linear regression. Aging, uric acid and LDL-cholesterol significantly influenced lag time.

Our results suggest that LDL oxidisability might been regulated by aging, changes in LDL-cholesterol with aging and variations in physical antioxidant function.

Key words : Aging, Atherosclerosis, LDL oxidisability, Antioxidants, LDL-cholesterol (Jpn J Geriat $2001 ; 38: 372-376$ )

1) Internal Medicine I, National Defense Medical College

2) Faculty of Human Life Science, Ibaraki Christian University

3) Institute of Environmental Science for Human Life, Ochanomizu University 